\title{
FORENSIC APPLICATIONS OF MITOCHONDRIAL CYTOCHROME $B$ GENE IN THE IDENTIFICATION OF DOMESTIC AND WILD ANIMAL SPECIES
}

\author{
Mayada R. Farag ${ }^{1 *}$, Khlood M. El Bohi ${ }^{1}$, Samah R. Khali1 ${ }^{1}$, Mahmoud Alagawany ${ }^{2 *}$, Muhammad \\ A. Arain ${ }^{3}$, Khan Sharun ${ }^{4}$, Ruchi Tiwari ${ }^{5}$, Kuldeep Dhama ${ }^{6}$ \\ ${ }^{1}$ Forensic Medicine and Toxicology Department, Veterinary Medicine Faculty, Zagazig University, Zagazig 44519, Egypt \\ ${ }^{2}$ Poultry Department, Faculty of Agriculture, Zagazig University, Zagazig 44519, Egypt \\ ${ }^{3}$ Faculty of Veterinary and Animal Sciences, Lasbela University of Agriculture Water and Marine Sciences, (LUAWMS), Uthal, Pakistan \\ ${ }^{4}$ Division of Surgery, ICAR-Indian Veterinary Research Institute, Izatnagar, Bareilly- 243 122, Uttar Pradesh, India \\ ${ }^{5}$ Department of Veterinary Microbiology and Immunology, College of Veterinary Sciences, UP Deen Dayal Upadhayay Pashu Chikitsa Vigyan Vishwavidyalay \\ Evum Go-Anusandhan Sansthan (DUVASU), Mathura, India -281001, India \\ ${ }^{6}$ Division of Pathology, ICAR-Indian Veterinary Research Institute, Izatnagar, Bareilly- 243 122, Uttar Pradesh, India
}

Received - January 11, 2020; Revision - February 15, 2020; Accepted - February 22, 2020

Available Online - February 25, 2020

DOI: http://dx.doi.org/10.18006/2020.8(1).1.8

\author{
KEYWORDS \\ Species identification \\ Mitochondria \\ Cytochrome b gene \\ Animals \\ Fish
}

\begin{abstract}
Identification of animal species based on biological samples such as blood, hair, bone, muscle and others is an important practice in forensic analysis of DNA, but need a standard analytical method particularly when the DNA is low or mixed. The mitochondrial genome contains several forensically informative nucleotide sequences (FINS) that can be utilized for both intra-species and inter-species differentiation. Mitochondrial DNA (mtDNA) has several advantages than nuclear genomes due to greater abundance in the samples and high number of copies in each cell. Therefore, amplification and sequencing of mtDNA genes could constitute relatively sensitive procedures in species identification even if the tested samples are old or degraded. Cytochrome b (Cyt b) gene is among the most important mitochondrial genes which have been used in forensic species identification. The polymerase chain reaction-restriction fragment length polymorphism (PCR-RFLP) analysis and sequencing of the mitochondrial cyt $\mathrm{b}$ gene could be used as a robust tool in identification of different animal species including domestic, wild and fish species and for determination of meat origin in processed food products due to the presence of species specific mutation sites. The mitochondrial cytochrome-b sequence based species identification has wide forensic and judicial applications.
\end{abstract}

* Corresponding author

E-mail: dr.mayadarf@gmail.com (Mayada R. Farag); mmalagwany@zu.edu.eg (M. Alagawany)

Peer review under responsibility of Journal of Experimental Biology and Agricultural Sciences.

Production and Hosting by Horizon Publisher India [HPI] (http://www.horizonpublisherindia.in/).

All rights reserved.
All the articles published by Journal of Experimental Biology and Agricultural Sciences are licensed under a Creative Commons Attribution-NonCommercial 4.0 International License Based on a work at www.jebas.org.

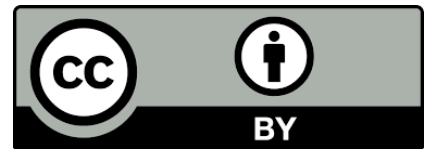




\section{Introduction}

Forensic identification of animal species and individualization of animal samples is important for many purposes, such as investigations of alleged crimes of wildlife, poaching, illegal trading and conservation of endangered animal species, attacking of animals, robbery of livestock or the determination of meat origin in meat products or identification of animal species in foods of animal origin (for religious and health purposes) (Bottero \& Dalmasso, 2011; Silva-Neto et al., 2016; Lopez-Oceja et al., 2016). Species identification using molecular-genetic or bio-molecular approaches is more reliable and specific than other methods such as immunological approaches based on antigen-antibody reactions which lack specificity and changed by environmental conditions (Tobe \& Linacre, 2008). Polymerase chain reaction-restriction fragment length polymorphism (PCR-RFLP) which involves the extraction of DNA, PCR, and the use of restriction enzymes to digest the PCR products is one of the most commonly used molecular techniques as it results in species-specific restriction pattern. However it is unable to identify unknown species in mixed samples (Fernandes et al., 2008; Spychaj et al., 2009). Amplification of specific region using universal primer and sequencing of such region to compare its sequence with the public database in GeneBank is more reliable to determine the most related sequence of unknown sample (Naidu et al., 2012; Muangkram et al., 2018). Mitochondrial DNA (mtDNA) is highly polymorphic and thousand copies of it are present inside each cell, therefore it's amplification and sequencing could be used as a powerful tool in species identification even in old or degraded samples (Bravi et al., 2004 ; Muangkram et al., 2018).

The mitochondrial cytochrome b (MT-cyt b) gene is one of the best known proteins that make up the complex III of oxidative phosphorylation system in the mitochondria and is the only one encoded by the mitochondrial genome. Cyt $b$ genes have been utilized as powerful indicators in species identification by analysis techniques of DNA (Andrejevic et al., 2019). It is also used in studies of forensic investigations, legal medicine and molecular evolution (Bataille et al., 1999; Wolf et al., 1999; Prusak et al., 2004). Species identification can be performed efficiently by using short fragments of MT-cyt b, especially in samples that are degraded or are low in DNA quantity (Andrejevic et al., 2019). While developing species specific primers, it is important to verify the primer specificity on other animal species so that the diagnostic test will remain as highly specific for the species against which it is developed (Kim et al., 2020). Cytochrome b (cyt -b) gene has species specific mutation sites making it useful for species identification, therefore, cyt b gene is extensively employed in systematic studies to resolve divergences at several taxonomic levels. The species identification studies depending on cyt $b$ gene are various including amplification of short $(<400$ base pair $)$ and long (>900 base pair) fragments using PCR-PFLP and sequencing in addition to variable size species-specific multiplex PCR (Matsunaga et al., 1999; Parson et al., 2000; Izeni et al., 2001; Bellis et al., 2003; Guha et al., 2006). The short fragment of cytochrome $b$ gene can be considered as the universal DNA barcode region of individual species. It can be used as an accurate and efficient tool for discriminating different domestic and wild animal species (Yacoub et al., 2013). This review highlights the role of the mitochondrial cytochrome $b$ gene in identification of different animal species including domestic, wild and fish species.

\section{Use of cyt b gene in identification of domestic animal species}

Bing et al. (1999) developed a technique that has successfully enabled the differentiation of DNA from human and non-human [Gallus gallus (chicken), Sus scrofa (pig), Bos taurus (cow) and Equus caballus (horse)] origins by amplifying the MT-cyt b and displacement loop (D-loop). Where, the amplification products were of one band for non-human DNA and as two bands for human. Such technique was also used by Bellis et al. ( 2003) to identify G. gallus (chicken), Ovis aries (sheep), Capra hircus (goat), B. taurus (cow), S.scrofa (pig), E. caballus (horse), Rattus noregicus (rat), Felis catus (domestic cat), Cnis familiaris (domestic dog) in addition to Panthera tigris tigris (Bengal tiger). The 127 bp long target fragment of MT-cyt b chosen by Andrejevic et al. (2019) for amplification using universal primers exhibited very low intraspecies genetic diversity ranging from 0 to $4.72 \%$. Whereas, the interspecies genetic diversity of the same fragments were very high $(8.36 \%$ to $42.52 \%)$, indicating great potential for species discrimination.

Nucleotide sequence analysis of cyt $\mathrm{b}$ gene was done by Parson et al. (2000) to identify DNA from 44 different animal species including birds, mammals, fishes, amphibians and reptiles. They stated that sequencing of cyt $b$ was very powerful and sensitive for identification of various samples even the problematic ones like feathers, hair and bristles. Similarly, Ramatla et al. (2019) could differentiate between rodent species which in the poultry farms in Mafikeng in South Africa by amplifying and sequencing of PCR products of cyt b gene. Similarly, Awad et al. (2015) partially sequenced a cyt b segment (358pb) which helped in identification of some avian species such as chicken (Gallus gallus), Japanese quail (Coturnix japonica), muskovy duck (Cairina moschata), rock pigeon (Columba livia), and laughing dove (Streptopelia senegalensis). The cytochrome $\mathrm{b}$ gene sequence based analysis is a very efficient tool that can be used to discriminate among native chicken strains and other species of Gallus gallus fowl (Yacoub et al., 2013). The PCR-RFLP of cytochrome $b$ gene was performed over 39 DNA samples collected from different meatball shops in Indonesia to confirm the contamination of sausage, nugget and meatballs with pork, and amplification of cytochrome $b$ gene was 
proved promising in detecting the meat contamination by another type of meat as 9 meat samples were found contaminated with porcine DNA (Erwanto et al., 2011; Erwanto et al., 2012; Erwanto et al., 2014). In another study, 565 blood-fed Culicoides females were collected from forest, pasture, donkey shelters and sheep shelters in France during 2012-2014. They were identified based upon morphological features and on the basis of Cyt b marker gene of mitochondrial DNA. Results showed that cyt b was suitable marker for confirmation of species (Hadj-Henni et al., 2015).

Identification of meat in foods and feedstuffs as well as processed meats is a matter of great importance due to many considerations related to health, religion and economic affairs (Farag et al., 2015a). Analyzing and sequencing the products of PCR- RFLP of cyt $b$ gene (359 bp amplicon was exposed to digestion by restriction enzymes to give species specific patterns by electrophoresis) helped in detecting the meat meal in the animal feed stuffs and identified the species of origin (Bellagamba et al., 2001). The same technique could identify animal species in processed food with chicken, pork and bovine meat (Pancorbo et al., 2004). Aina et al. (2019) used cyt b gene to identify wild boar meat in meatball products.

PCR-RFLP of cyt be gene has been also used by Bravi et al. (2004) who amplified a fragment from cyt $b$ gene from human, cattle, pig, sheep, donkey, horse, cat, dog, chicken and rabbit from blood and meat samples using universal primers and the restriction enzymes (Hae III , Alu I, and Hinf I). Similarly, Abdel-Rahman et al. (2009) developed a PCR and PCR-PFLP technique to identify dog's, cat's, horse's and donkey's meat. Moustafa et al. (2017) could differentiate between horse and donkey (Equus asinus) species using the same technique. Additionally, Farag et al. (2015b) used the PCR-RFLP analysis of cyt be gene to identify domestic species such as camel, buffalo and sheep. Donkey-specific primer pairs developed from mitochondrial cytochrome $\mathrm{b}$ gene was found to be effective in detecting raw donkey meat as well as different meat mixtures like grinded, boiled, fried, roasted, dried, and autoclaved meat (Kim et al., 2020). The specificity of the developed donkeyspecific primers was also verified using 20 animal species.

PCR-RFLP of cyt $b$ gene succeeded in identification of cattle (Bos Taurus), goat (Capra hircus), sheep (Ovis aries), red deer (Cervus elaphus) and roe buck (Capreolus capreolus) from blood traces obtained from a leaf which is considered as unknown source (Pfeiffer et al., 2004).

Species specific repeat (SSR) and PCR-RFLP analysis of cyt b gene were effective in identification of meat samples from cattle, buffalo, sheep and pig (Ahmed et al., 2007). Novianty et al. (2017) used a genetic marker of cyt b by duplex-PCR to identify pork contamination in meatballs. Jain et al. (2007) used multiplex PCR analysis of cyt $b$ gene for identification of sheep, goat, buffalo, chicken, horse and pig meat through mixing different ratios of species specific primers .Similar results were obtained by Matsunaga et al. (1999) for all the same species except buffalo. By using the same primers in different ratios, Obrovska et al. (2002) also obtained species specific bands for cattle, horse, pig and chicken. RT-PCR that uses specific primers targeting MT-cyt b gene is considered as the standard detection tool for identifying the presence of pork in food samples intended for halal consumption (Orbayinah et al., 2019). They designed the primer 5'-ACG CGA TAT AAG CAG GTA AA-3' (forward); and 5'-CTG CTT TCG TAG CAC GTA TT-3' (reverse) which was found to be effective in detecting pork meatball formulations at different series of dilution.

Tobe \& Linacre (2008) could design species specific primers based on single nucleotide polymorphism (SNPs) in the cyt b gene through collecting the sequences obtained from Gene bank and used them to identify various animal species including dog, cat, cow, donkey, horse, pig, house mouse (M. musculus), human ( $H$. sapien), lamb (O. aries), rat, rabbit (O. cuniculus), guinea pig $(C$. porcellus) in addition to fox (V. vulpes), badger (M. meles) and red deer (C. elaphus)

\section{Use of cyt b gene in identification of wild animal species}

Wildlife forensics using cytochrome b is an applied aspect of new DNA based technologies for identification of wildlife species (Ogden et al., 2009). Matsunaga et al. (1998) used cyt b gene sequence to design species-specific primers to identify the meat of dear in meat products and meat and could distinguish red and sika dear from bovine, sheep and pigs. To differentiate between sika deer and red deer they exposed the PCR products to digestion by restriction enzymes (EcoRI, ScaI, and BamHI). The fragment of red deer was digested by EcoRI only into two fragments $(67+$ $127 \mathrm{bp}$ ). While, the fragment of sika deer fragment was digested by ScaI and BamHI to $49+145$ bp and $48+146$ bp fragments. They discriminated between the two deer kinds from the digestion pattern of restriction enzymes. In Zambia, to identify the origin of meat from wild animals, among 29 animals of eleven species of bovidae mitochondrial DNA, mainly cytochrome b (Cytb) and cytochrome oxidase I (COI) were used as chief target for PCR and sequencing (Lynch \& Jarrell, 1993; Syakalima et al., 2016). The presence of forensically informative nucleotide sequences (FINS) in the mitochondrial genome of Indian antelope or Blackbuck (Antilope cervicapra) were evaluated and found the presence of FINS in the Cytochrome Oxidase I, Cytochrome b, and 16S rRNA genes (Shukla et al., 2019). The identified FINS can be used for both intra-species and Inter-species differentiation studies in this wild animal species.

Zhang \& Ryder (1998) could differentiate between old world monkeys (Maccaca mulatta, Mandrillus leucophaeus, Mandrillus 
sphinx, Semnopithecus entellus, T. johni, T. francoisi, T. phagrei, Rhinopithecus roxellanae, Trachypithecus vetulus, Pygathrix nemaeus, $R$. avunculus, $R$. bieti, Nasalis larvatus and Colobus polykomos) using the partial sequence of the cyt $\mathrm{b}$ gene segment (393-402 bp) .

Cook et al. (1999) partially sequenced $450 \mathrm{bp}$ fragment of the cyt b gene and 512 bp from mitochondrial control region and could determine the monophyletic of sika deer by studying 28 individuals of sika deer subspecies. Partial DNA sequence of cyt b (402 bp fragments) has been used by Hsieh et al. (2001) to identify endangered species in Tiwan from the remains of Formosan gemfaced civets, lion, tigers, leopard cats, clouded leopards, water buffalo, Formosan muntjacs, Formosan sambars, Formosan sika deers, Formosan serows,, Formosan macaques and Formosan pangolins. Then the resulting sequences were compared with some domestic species such as dogs, cats, sheep, pigs, cattle and humans. Endangered and domestic animals of the same species could be clustered in the neighbour-joining tree.

Hsieh et al. (2003) used a partial sequence of cyt b (402 bp) to identify and determine the phylogenetic relationship of rhinoceros horns species and found that there were 4 major branches among this species based on GeneBank sequences. On a similar ground, Hsieh et al. (2005) used a partial sequence of cyt b to identify tortoises using 100 shell samples from the species Kachuga tecta. They could classify them in to 4 haplotypes of DNA sequences as follows; haplotype I and II (K. tecta), haplotype III (Morenia ocellata) and haplotype IV (Geoclemys hamiltonii) compared to GeneBank sequences.

Nagata et al. (2005) used the PCR- RFLP of cyt b gene to develop species-specific primers for identification of the leopard Panthera pardus and tiger Panthera tigris from domestic dog, domestic cats and red fox, roe deer, red deer, sika deer, wild boar and humans. Quantitative polymerase chain reaction (q-PCR) using species specific primers (forward: 5'-CGG TTC CCT CTT AGG CAT TT3'; Reverse: 5'-GGA TGA ACA GGC AGA TGA AGA-3') that targets MT-cyt $b$ gene can be used for the detection of wild boar meat. This has great application both in wildlife forensics as well as in the identification of non-halal meats in commercial meat products (Aina et al., 2019).

PCR- RFLP of cyt be gene has been also used by Abo-Hadeed et al. (2011) to identify some non-domestic animals (American black bear (Urus americanus), Blue Nile monkey (Ceropithecus mitis), Bactrian camel (Camelus bactrianus) Barbary sheep (Amotracus lervia), and Llama (Lama glama) from hair samples by amplifying a fragment from cyt $b$ gene (358pb) using universal primers and the restriction enzymes (Hae III, Alu I, and Hinf I). Differentiating the wild and domestic population of animal species is necessary to resolve certain categories of judicial cases. Gonzalez et al. (2020) made an attempt to differentiate among domestic, wild and hybrid camelids of South America. MT-cyt b genetic variation was found to be an ideal tool for distinguishing between Lama and Vicugna (Gonzalez et al., 2020).

Partial sequence of cyt $b$ succeeded in identifying the origin of unknown samples. The first one was ornithological trace "a hair from a bird nest" related by cyt b to goat $(100 \%$ similarity with GneBank sequence). The second sample was forest trace "blood stain from Notecka forest in Poland and related by cyt b to elk (Alces alces) with $97.8 \%$ similarity. The third one was zoological trace "muscle fragment of a dead reptile from Zoological Garden in Warsaw and related by cyt b to the endangered species "Python molurus" (Prusak et al., 2005).

Yan et al. (2005) used various sequences of cyt b gene to design species specific PCR primer for identification of the protected species "Chinese alligators" and other species of crocodilians. Additionally, Cyt b gene has helped in developing of speciesspecific markers for identification of eight endangered Indian Pecoran species (Guha et al., 2006).

Lee et al. (2009) used nested PCR within cyt b for identification of endangered and protected elephant species using highly degraded DNA ivory samples (360African savanna elephants "Loxodonta africanta", 14 African forest sample "Loxodonta cyclotis" and 8 Asian elephants). The resulting sequences matched with GeneBank sequences of Loxodonta and $E$. maximus species with about $99 \%$ of similarity.

\section{Use of cyt $b$ in identification of fish species}

Izeni et al. (2001) stated that cyt be could be utilized as a molecular marker in establishing of the phylogenetic tree of the fish family Cichidae. Aranishi et al. (2005) optimized a rapid PCR-PFLP technique to distinguish the occurrence of 3 closely related species of gadoid fish: Alaska Pollack "Theragra chalcogrmma", Atlantic cod "Gadus morhua" and Pacific cod "Gadus macrcephalus" in commercial products of sea foods. They designed a universal primer for Gadoid to amplify a cyt b gene fragment (558 bp) which was then exposed to digestion with the restriction enzymes Eco105I and Eco32I which gave 2 fragments in Pacific cod, 3 fragments in Alaska Pollack and no cleavage in Atlantic cod.

Akasaki et al. (2006) used the PCR-RFLP analysis of cyt b (385 bp) and restriction enzymes (MseI, MboI, FokI, and AluI) as a rapid screening method to identify imported products of cod fish in Japan. With the same technique, Wu et al. (2008) could identify commercial species of Aluterus scriptus , Aluterus monoceros, , Monacanthus chinensis, , Thamnaconus modestus, Thamnaconus hypergyrus and Chaetodermis penicilligerus. They designed H15149and L14735 in the cyt b gene to amplify a 465bp fragment 
from processed meats of filefish. Then the resulting fragments were digested by HaeIII enzyme which gave species-specific pattern for each species;, A. scriptus $(180+159+126 \mathrm{bp})$, A. monoceros ( $285+180 \mathrm{bp})$, M. chinensis $(424+41 \mathrm{bp})$, T. modestus $(229+180+56 \mathrm{bp}), T$. hypergyrus $(180+159+94+32$ bp) and $C$. penicilligerus $(285+139+41 \mathrm{bp})$. The mitochondrial cyt $\mathrm{b}$ sequence of Catla catla was found to be highly variable among the wild and cultured populations. It is also interesting to note that the genetic distance between the wild populations were more compared to the cultured populations. The genetic distance between the cultured populations were found to be almost absent or present at very low values indicating that cyt $\mathrm{b}$ sequence is highly conserved (Garg \& Mishra, 2018).

\section{Conclusion and Future Prospects}

The use of cyt $b$ gene for species identification has been shown to be a simple, reliable and sensitive method which allows analysis of minute amount of DNA even in old and highly degraded samples and could determine the origin of biological evidences from different domestic and wild animals, and fish species even in the absence of reference samples. Mt- cyt b gene is highly conserved among different species at the same time shows diversity among the different unrelated populations of the same species. Hence, it can be used as a marker to differentiate among different animal species and also has potential for identifying ecological habitat based on the genetic diversity among different populations. Species identification based on molecular tools that targets mitochondrial cyt $b$ gene has wide forensic and judicial applications.

\section{Acknowledgement}

All the authors acknowledge and thank their respective Institutes and Universities.

\section{Author contributions}

All the authors substantially contributed to the conception, design, analysis and interpretation of data, checking and approving final version of the manuscript, and agree to be accountable for its contents.

\section{Funding}

This compilation is a review article written, analyzed and designed by its authors and required no substantial funding to be stated.

\section{Conflicts of interest}

All authors declare that there exist no commercial or financial relationships that could, in any way, lead to a potential conflict of interest.

\section{References}

Abdel-Rahman SM, El-Saadani MA, Ashry KM, Haggag AS (2009) Detection of adulteration and identification of cats, dogs, donkeys and horses meat using species specific PCR and PCRRFLP techniques. Australian Journal of Basic and Applied Sciences 3: 1716-1719.

Abo-Hadeed AH, Mervat HG, Mayada RF (2011) Species identification of some non-domestic animals using PCR-RFLP analysis of cytochrome b gene. Zagazig Veterinary Journal 39: 3746.

Ahmed MMM, Abdel-Rahman SM, El-Hanafy AA (2007) application of species specific polymerase chain reaction and cytochrome $\mathrm{b}$ gene for different meat species authentication. Biotechnology 6: 426-430.

Aina GQ, Erwanto Y, Hossain M, Johan MR, Ali MdE, Rohman A (2019) The employment of q-PCR using specific primer targeting on mitochondrial cytochrome-b gene for identification of wild boar meat in meatball samples. Journal of Advanced Veterinary and Animal Research 6: 300-7.

Akasaki T, Yanagimoro T, Yamakami K, Tomonaga H, Sato S (2006) species identification and PCR-RFLP analysis of cytochrome b gene in cod fish (Order Gadiformes) products. Journal of Food Science 71: 190-195.

Andrejevic M, Markovic, MK, Bursac B, Mihajlovic M, Keckarevic D (2019) Identification of a broad spectrum of mammalian and avian species using the short fragment of the mitochondrially encoded cytochrome b gene. Forensic Science, Medicine and Pathology 15:169-177.

Aranishi F, Okimoto T, Izumi S (2005) Identification of gadoid species (Pisces, Gadidae) by PCR-RFLP analysis. Journal of Applied Genetics 46: 69-73.

Awad A, Khalil SR, Abd-Elhakim YM (2015) Molecular phylogeny of some avian species using Cytochrome b gene sequence analysis. Iranian Journal of Veterinary Research 16: 218-222.

Bataille M, Crainic K, Leterreux M, Durigon M, de Mazancourt P (1999) Multiplex amplification of mitochondrial DNA for human and species identification in forensic evaluation. Forensic Science International 99:165-70.

Bellagamba F, Moretti VM, Comincini S, Valfre F (2001) Identification ofspecies in animal feeds us by polymerase chain reaction-restriction fragment lengthpolymorphism analysis of mitochondrial DNA. Journal of Agriculture and Food Chemistry 49: 3775-3781 
Bellis C, Ashton KJ, Freney L, Blair B, Griffiths LR (2003) A molecular genetic approach for forensic animal species identification. Journal of Forensic Science International 134:99-108.

Bing SU, Wang YX, Lan H, Wang W, Zjang Y (1999) phlogenetic study of complete cytochrome b genes in Musk deer (Genus Moschus) using Museum samples. Journal of Molecular Phylogenetics and Evolution 12: 241-249.

Bottero MT, Dalmasso A (2011) Animal species identification in food products: Evolution of biomolecular methods. Veterinary Journal 190:34-38.

Bravi CM, Liron JP, Mirol PM, Ripoli MV, Garcia PP, Giovambattista G (2004) A simple method for domestic animal identification in Argentina using PCR-RFLP analysis of cytochrome b gene. Journal of Legal Medicine 6:246-251

Cook CE, Wang Y, Sensabaugh G (1999) A mitochondrial control region and cytochrome b phylogeny of sike deer (Cervus nippon) and report of tandem repeats in the control region. Molecular Phylogenetics and Evolution 12: 47-56.

Erwanto Y, Abidin MZ, Rohman A, Sismindari (2011) PCR-RFLP Using BseDI enzyme for pork authentication In sausage and nugget products. Media Peternakan-Journal of Animal Science and Technology 34:14-18.

Erwanto Y, Abidin MZ, Sismindari , Rohman A (2012) Pig species identification in meatballs using polymerase chain reactionrestriction fragment length polymorphism for halal authentication. International Food Research Journal 19:901-906.

Erwanto Y, Abidin MZ, Sugiyono EYPM, Rohman A (2014) Identification of Pork Contamination in Meatballs of Indonesia Local Market Using Polymerase Chain Reaction-Restriction Fragment Length Polymorphism (PCR-RFLP) Analysis. AsianAustralasian Journal of Animal Sciences 27: 1487-1492.

Farag MR, Alagawany M, Abd El-Hack ME, Tiwari R, Dhama K (2015b). Identification of different animal species in meat and meat products: trends and advances. Advances in Animal and Veterinary Sciences 3: 334-346.

Farag MR, Imam TS, Dhama K (2015a) Identification of some domestic animal species (camel, buffalo and sheep) by PCR-RFLP analysis of the mitochondrial cytochrome $b$ gene. Advances in Animal and Veterinary Sciences 3: 136-142.

Fernandes CA, Ginja C, Pereira I, Tenreiro R, Bruford MW, Santos Reis M (2008) Species-specific mitochondrial DNA markers for identification of non-invasive samples from sympatric carnivores in the Iberian Peninsula. Conserve Genetics 9:681-90.
Garg RK, Mishra V (2018). Molecular insights into the genetic and haplotype diversity among four populations of Catla catla from Madhya Pradesh revealed through mtDNA cyto $b$ gene sequences. Journal of Genetic Engineering and Biotechnology 16: 169-174.

Guha S, Goyal S, Kashyap VK (2006) Genomic variation in the mitochondrially encoded cytochrome b (MT-CYB) and 16S rRNA (MT-RNR2) genes: Characterization of eight endangered Pecoran species. Animal Genetics 37:262-5 .

Gonzalez BA, Agapito AM, Novoa-Munoz F, Vianna J, Johnson WE, Marin JC (2020) Utility of genetic variation in coat color genes to distinguish wild, domestic and hybrid South American camelids for forensic and judicial applications. Forensic Science International: Genetics 45: 102226.

Hadj-Henni L, De Meulemeester T, Depaquit J, Noel P, Germain A, Helder R, Augot D (2015) Comparison of Vertebrate Cytochrome b and Prepronociceptin for Blood Meal Analyses in Culicoides. Frontiers in Veterinary Science 2: 15.

Hsieh HM, Chiang HL, Tasi LC, Lai SY, Huang NE, Linacre A, Lee JCI (2001) Cytochrome b gene for species identification of the conservation animals. Forensic Science International 122: 7-18.

Hsieh HM, Huang LH, Tsai LC, Kuo YC, Meng HH, Linarce A, Lee JC (2003) species identification of rhinoceros horns using the cytochrome b gene. Forensic Science International 136: 1-11.

Hsieh HM, Huang LH, Tsai LC, Liu CL, Kuo YC, Hsiao CT, Linarce A, Lee JC (2005) species identification of Kachuga tecta Using the Cytochrome b Gene. Journal of Forensic Science 51: 5256.

Izeni PF, Ortí G, Sampaio I, Schneider H, Meyer A (2001) The Cytochrome $b$ gene as a phylogenetic marker: the limits of resolution for analyzing relationships among cichlid fishes. Journal of Molecular Evolution 53:89-103.

Jain S, Brahmbhait MN, Rank DN, Joshi CG, Solank JV (2007) Use of cytochrome $b$ gene variability in detecting meat species by multiplex PCR assay. Indian Journal of Animal Sciences 77: 880881.

Kim MJ, Suh S M, Kim SY, Qin P, Kim HR, Kim HY (2020) Development of a Real-Time PCR Assay for the Detection of Donkey (Equus asinus) Meat in Meat Mixtures Treated under Different Processing Conditions. Foods 9: pii: E130.

Lee JC, Hsieh HM, Huang LH, Kuo YC, Wu JH, Chin SC, Lee AH, Linacrre A, Tasi LC (2009) Ivory identification by DNA profiling of cytochrome $\mathrm{b}$ gene. International Journal of Legal Medicine 123: 117-121.

Journal of Experimental Biology and Agricultural Sciences http://www.jebas.org 
Lopez-Oceja A, Gamarra D, Borragan S, Jimenez-Moreno S, de Pancorbo MM (2016) New cyt b gene universal primer set for forensic analysis. Forensic Science International and Genetics 23:159-65.

Lynch M, Jarrell PE (1993) A method for calibrating molecular clocks and its application to animal mitochondrial DNA. Genetics 135: $1197-1208$.

Matsunaga T, Chikuni K, Tanabe R, Muroya S, Nakai H, Shibata K, Shinmura YJY (1998) Determination of mitochondrial cytochrome b gene sequence for red deer (Cervus eleaphus) and differentiation of closely related deer meats. Journal of Meat Science 49: 379-385.

Matsunaga T, Chikuni K, Tanabe R, Muroya S, Shibata K, Yamada J. Shinmura Y (1999) A quick and simple method for the identification of meat species and meat product by PCR assay. Meat Science 51: 143-8.

Moustafa GG, Abd Elhakim YM, El Sharkawy NI (2017) genetic profiling of equid hybrids using PCR-RFLP and partial sequence analysis of cytochrome $b$ gene: forensic implication. Journal of Equine Veterinary Science 54: 37-41.

Muangkram Y, Wajjwalku W, Amano A, Sukmak M (2018) The novelprimers for mammal species identification-based mitochondrial cytochrome $\mathrm{b}$ sequence: implication for reserved wild animals in Thailand and endangered mammal species in Southeast Asia. Mitochondrial DNA Part A, DNA mapping, sequencing, and analysis 29:62-72.

Nagata J, Aramilev VV, Belozor A, Sugimoto T, McCullough DR (2005) Fecal genetic analysis using PCR-RFLP of cytochrome b to identify sympatric carnivores, the tiger Panthera tigris and leopard Panthera pardus, in far eastern Russia. Conservation Genetics 6: 863-865.

Naidu A, Fitak RR,Munguia-Vega A, Culver M (2012) Novel primers for complete mitochondrial cytochrome $\mathrm{b}$ gene sequencing in mammals. Molecular Ecology Resources 2:191-6.

Novianty E, Kartikasari LR, Lee JH, Cahyadi M (2017) Identification of pork contamination in meatball using genetic marker mitochondrial DNA cytochrome $b$ gene by duplex-PCR. IOP Conf. Ser.: Materials Science and Engineering 193: 012-002.

Obrovska I, Steinhauserova I and Nebola M (2002) The application ofthe PCR method to the identification of meat species. Folia Veterinaria 46: 113-18.

Ogden R, Dawnay N, McEwing R (2009) Wildlife DNA forensics - bridging the gap between conservation genetics and law enforcement. Endangered Species Research 9: 179-195.
Orbayinah S, Widada H, Hermawan A, Sudjadi S, Rohman A (2019) Application of real-time polymerase chain reaction using species specific primer targeting on mitochondrial cytochrome-b gene for analysis of pork in meatball products. Journal of Advanced Veterinary and Animal Research $6: 260-265$.

Pancorbo MMD, Casro A, Fernandez IF, Cuevas N (2004) Cytochrome $b$ for identification of animal species in processed food. International Congress Series 1261: 592-594.

Parson W, Pegoraro K, Niederstatter H, Foger M, Steinlechner M (2000) Species identification by means of the cytochrome $b$ gene. International Journal of Legal Medicine 114: 23-8

Pfeiffer I, Burger J, Brenig B (2004) Diagnostic polymorphisms in the mitochondrial cytochrome $b$ gene allow discrimination between cattle, sheep, goat, roe buck and deer by PCR-RFLP. BMC Genetics 5:1-5.

Prusak B, Grzybowski T, Bednarek J (2005) Cytochrome b gene (cytb) in analysis of anonymous biological traces and its application in veterinary diagnostics and animal conservation. Animal Science Papers and Reports 23: 229-236

Prusak B, Grzybowski G, Zieba G (2004) Taxonomic position of Bison bison (Linnaeus, 1758) and Bison bonasus (Linnaeus, 1758 ) based on analysis of $c y t b$ gene. Animal Science Paper and Reports 22: 27-35.

Ramatla T, Mphuthi N, Gofaone K, Taioe MO, Syakalima1 M (2019) Identification of rodent species that infest poultry houses in mafikeng, north west province. South Africa International Journal of Zoology https://doi.org/10.1155/2019/1280578.

Shukla MA, Joshi BD, Kumar VP, Mehta AK, Goyal SP (2019) Investigating the genetic diversity and presence of forensically informative nucleotide sequences in Indian antelope (Antilope cervicapra) using multiple genes of the mitochondrial genome. Molecular Biology Reports 46 : 6187-6195.

Silva-Neto A, Ferreira PB, Torresb RA, Texeirac RHF, Duarted JMB, Barbosae A, Vargase RC, Garciaa JE (2016) Diagnostic Cytochrome b gene profiles for the identification of paca (Cuniculus paca) bushmeat: implications for the monitoring of illegal hunting and wildlife trade. Brazilian Journal of Biology 76:55-58.

Spychaj A, Mozdzaik EP, Pospiech E (2009) PCR methods in meat species identification as a toll for the verification of regional and traditional meat products. Acta Scientiarum Polonorum, Technologia Alimentaria 8:5-20. 
Syakalima M, Munyeme M, Yasuda J (2016) Cytochrome c Oxidase Sequences of Zambian Wildlife Helps to Identify Species of Origin of Meat. 2016:6.

Tobe SS, Linacre A (2008) A method to identify a large number of mammalian species in the UK from trace samples and mixtures without the use of sequencing. Journal of Forensic Science International: Genetic supplement series 625-627.

Wolf C, Rentsch J, Hubner P (1999) PCR-RFLP analysis of mitochondrial DNA: a reliable method for species identification. Journal Agriculture of Food Chemistry 47:1350-5.

Wu Ya-Jung, Hsieh CH, Chen HM, Hwang DF (2008) identification of six common species of processed filefish using cutochrome $b$ gene sequence and PCR-RFLP analysis. The Rraffles Bulletin of Zoology Supplement 19: 151-158.

Yacoub HA, Fathi MM, Mahmoud WM (2013) DNA barcode through cytochrome $b$ gene information of mtDNA in native chicken strains. Mitochondrial DNA 24 : 528-537.

Yan PX, Wu P, Shi Y, Gu CM, Wang RP, CL Wang (2005) identification of Chinese alligators (Alligator sinensis) meat by diagnostic PCR of the mitochondrial cytochrome $b$ gene. Journal of Biological Conservation 121:45-51.

Zhang, Y, Ryder OA (1998) Mitochondrial cytochrome b gene sequences of old world monkeys: With special reference on evolution of Asian colobines. Primates 39: 39-49. 